\title{
Transferência da Comissão de Classificação de Cargos para o Estado da Guanabara
}

A Comissão de Classificação de Cargos, com o objetivo de melhor dinamizar as suas atividades, transferiu-se a 16 de julho do corrente ano, da Capital Federal para o Estado da Guanabara.

Como fator determinante da medida agora objetivada, situamos as dificuldades de tôda ordem que o funcionamento da Comissão em Brasilia suscitava, uma vez que as Divisões de Pessoal dos Ministérios e os Grupos de Trabalko que militam no setor de enquadramento e classificação operam ainda na antiga capital.

Tendo sido criada sob forma de colegiado - característica comum aos órgãos dêste gênero - a C.C.C. tem, atualmente, como componentes de seu Conselho, os seguintes membros:

Presidente - Paulo Poppe de Figueiredo.

Vice-Presidente - Auro Bastos de Roure.

Membros - Eloah Meirelles Gonçalves Barreto (Diretora da Divisão de Seleção e Aperfeiçoamento do D.A.S.P.) - Ruy Vieira da Cunha (Diretor da Escola de Serviço Público do D.A.S.P.) - Raymundo Xavier de Menezes (Membro nato, pela qualidade de Diretor da Divisão de Classificação de Cargos do D.A.S.P.)

Intensa tem sido a atividade da C.C.C. no Rio de Janeiro, com a realização de sessões diárias, durante as quais foi ultimado um nôvo Regimento Interno consubstanciado no Decreto n? 56.877, de 20-9-65 - que disciplina sua nova fase de realizaçōes. 